\title{
The genus Boltovskoyella (foraminifera) from Patagonia
}

\author{
CAROLINA NÁÑEZ \\ Dirección Nacional del Servicio Geológico, Conicet and Universidad de Buenos Aires, Tte. Fgta. Benito Correa 1194, (1107) Buenos Aires, \\ Argentina.
}

\begin{abstract}
Four species of the genus Boltovskoyella Malumián \& Masiuk are recognized in Patagonia, among them, B. paleocenica sp. nov., which is described from Danian shallow marine sediments. Considering that the previous records of Boltovskoyella are from the Middle-Late Eocene, this new species represents the oldest known occurrence of the genus. Boltovskoyella seems to be endemic to Patagonia, shows opportunistic features and prefers temperate-warm water settings. J. Micropalaeontol. 17(2): 105-118, December 1998.
\end{abstract}

\section{INTRODUCTION}

Since its description, Boltovskoyella Malumián \& Masiuk has been regarded as restricted to the Eocene-Oligocene of southernmost South America and New Zealand (Malumián \& Masiuk, 1972). The two species described from Patagonia are some of the most characteristic Middle-Late Eocene species endemic to the Austral Basin (Malumián, 1994). Both frequently dominate low diversity assemblages of shallow marine environments. The New Zealand record is considered to belong to another genus.

Collection across the Cretaceous-Palaeogene boundary in northwestern Patagonia has yielded a new species of Boltovskoyella from the Danian. The main purpose of this paper is to describe the new species in the context of a compilation of Boltovskoyella in Patagonia.

\section{STRATIGRAPHIC SETTING}

The marine Palaeogene of Argentina occurs mainly in Patagonia, where it was deposited in several basins by generally shallow seas, resulting in transgressive and regressive successions of alternating marine and non-marine sediments with marked hiatuses. The basins have always been in temperate latitudes with restricted access to the open ocean, so planktonic numbers are low and correlation with standard $P$ zones, if attainable, is generally indirect. There is no record of larger foraminifera. Three major Palaeogene transgressions occurred in Patagonia. The first began in the Maastrichtian and persisted into the Danian; the latter contains a cosmopolitan Midway-type foraminiferal assemblage. The second transgression (MiddleLate Eocene), contains several endemic species (Malumián, 1994). The third (Oligocene-Early Miocene) carries an assemblage with subantarctic influence (Malumián \& Náñez, 1991).

\section{MATERIAL}

Specimens were studied from the following localities (Fig. 1); references are given for additional information on associated foraminifera and stratigraphy.

\section{Danian, Neuquén Basin}

- Eastern edge of the Añelo Low, Neuquén province, Roca Formation, Puesto sin Nombre, Opaso and Bajada del Jagüel sections (Bertels, 1980; Uliana \& Dellape, 1981; Concheyro \& Náñez, 1994; Ardolino \& Franchi, 1997; Náñez \& Concheyro, 1997).

- Cerros Bayos, La Pampa province, Roca Formation, Cerros Bayos section (Leanza \& Hugo, 1985; Casadio \& Concheyro, 1992).

- General Roca, Río Negro province, type section of the Roca Formation (Bertels, 1964). Micropalaeontological collection, University of Buenos Aires.

\section{Middle-Late Eocene, Austral Basin}

- LA. x-1 La Aurora well, Santa Cruz province, Man Aike Formation?. Cutting samples from 645-655 mbsl (metres below sea level) and 665-675 mbsl (type sample of Boltovskoyella argentinensis Malumián \& Masiuk).

- Río Turbio coal measures area, Santa Cruz province, Rio Turbio Formation (Carrizo et al., 1990; Malumián \& Caramés, 1997).

(a) Upper member. Horizons below the coal seams: core samples from the Adaro II well, 448.5 masl (metres above sea level). Horizons above the coal seams: core samples from the D-60 well, 573-579 mbsl.

(b) Lower member. Section on the southern flank of the anticline north of San José dam, studied as part of a graduate thesis (Torre, pers. comm.).

- SC-1 well, Santa Cruz Province, Man Aike Formation (Malumián et al., 1971; Malumián \& Ramos, 1984). Core samples from 571-578 mbsl and $630 \mathrm{mbsl}$ (type sample of Boltovskoyella patagonica Malumián \& Masiuk).

- Gran Bajo de San Julián, southeast of the Laguna del Carbón, Santa Cruz province, Man Aike Formation. At the base of the outcropping Palaeogene succession (Malumián \& Náñez, 1989; Náñez, 1990).

- CB. es-6 Campo Bola well, Santa Cruz province, Man Aike Formation. Cutting samples from 594-604 and 654-664 mbsl (Náñez, 1990).

- SEC-7 well, Santa Cruz province, Man Aike Formation. Core samples from 114 and 117 mbsl (Malumián, 1992).

- Near La Aurelia Farm, Tierra del Fuego Island, La Despedida Formation, upper member. $540 \mathrm{~m}$ above the base of the section (Malumián, 1989). 


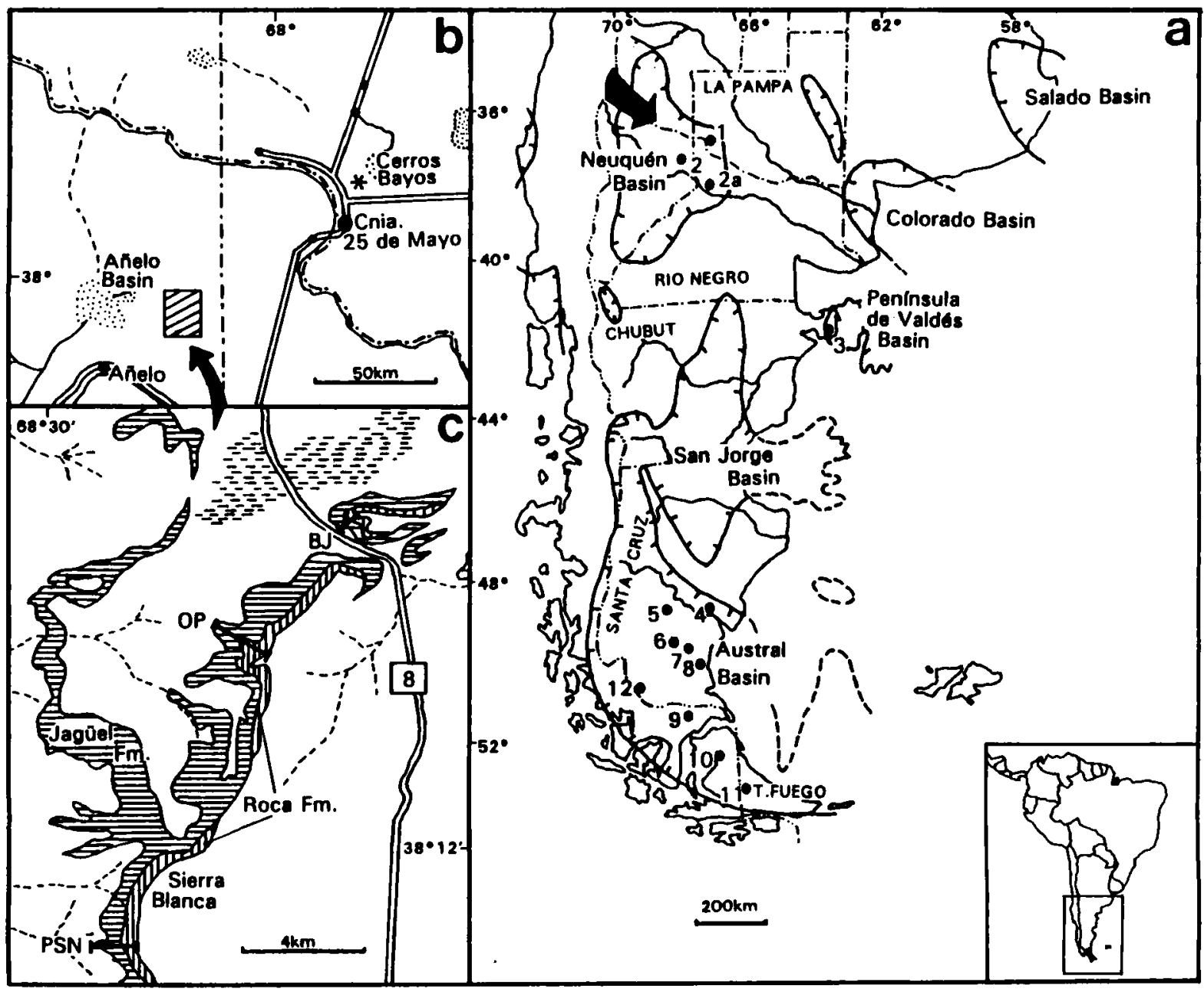

Fig. 1. (a) Main Cretaceous-Cenozoic Basins of southern South America and studied localities. 1, Cerros Bayos. 2, Añelo Low. 2a, General Roca. 3, Ch. PV. es-1 Península de Valdés well. 4, Gran Bajo de San Julián. 5, SEC-7 well. 6, LA. x-1 La Aurora well. 7, CB. es-6 Campo Bola well. 8, SC-1 well. 9, Ciaike no. 1 well. 10, Puerto Nuevo and Santa Clara Formations. 11, La Aurelia Farm. 12, Río Turbio area (D-60 and Adaro II wells). (b) Location of the Cerros Bayos section and study area at the eastern edge of the Añelo Low. (c) Location of Puesto sin Nombre (PSN), Opaso (OP) and Bajada del Jagüel (BJ) sections (modified from Náñez \& Concheyro, 1997). Geological map modified from Ardolino et al. (1995).

Additionally, type material of Asterigerina primaria Plummer and Heminwayina zealandica Hornibrook was available for study.

\section{DISTRIBUTION OF THE GENUS BOLTOVSKOYELLA}

Three species were included in the original description of the genus (Malumián \& Masiuk, 1972). The type species $B$. argentinensis was described from beds tentatively assigned to the Late Eocene, and $B$. patagonica from the Oligocene, probably Early Oligocene; both species were recorded from the subsurface of the Austral Basin, Argentina. The third species is Heminwayina zealandica, described by Hornibrook (1961) from the Eocene and Oligocene of New Zealand; this taxon is not now considered a Boltovskoyella, as is discussed under the systematic descriptions. Later, Masiuk et al. (1976) mentioned a new species of Boltovskoyella from the subsurface of the Península de Valdés Basin, Argentina, from beds dated as
Eocene, although it was neither figured nor described.

At that time, in Argentina the genus was known only from the subsurface, being dominant in low diversity assemblages which lacked planktonic foraminifers. This conspicuous occurrence led to the recognition of a 'Boltovskoyella assemblage' or 'Boltovskoyella beds' (Malumián, 1982; Malumián \& Ramos, 1984).

The stratigraphical and geographical distribution of the four species of Boltovskoyella ( $B$. argentinensis, B. patagonica, $B . \mathrm{sp}$. cf. $B$. patagonica and $B$. paleocenica sp. nov.) are indicated below: Boltovskoyella paleocenica sp. nov, is recorded from the Danian of the Neuquén Basin, northwestern Patagonia, from outcrops of the Roca Formation. The first micropalaeontological studies on the type section of the Roca Formation indicated an Early Danian age (Bertels, 1964). At Añelo Low, the Roca Formation was assigned a Late Danian age (NP4 Zone, of Martini, 1971 and P2 Zone, of Blow, 1979) based on the occurrence of the nannofossils Chiasmolithus edwardsii Romein, Neochiastozygus saepes Perch-Nielsen, N. perfectus Perch- 
Nielsen and Nodosella elegans Perch-Nielsen, and the planktonic foraminifers Globoconusa daubjergensis (Brönnimann) and 'Globorotalia (T.)' rainwateri Blow (Concheyro \& Náñez, 1994; Náñez \& Concheyro, 1997). At Cerros Bayos, a Danian age was based on the occurrence of Subbotina triloculinoides (Plummer) and Globoconusa daubjergensis, benthic foraminifers and ostracods (Musacchio, in Leanza \& Hugo, 1985), whereas an Early Danian age (NP1 Zone of Martini, 1971) was assigned by means of nannofossils (Casadío \& Concheyro, 1992).

The new species of Boltovskoyella mentioned by Masiuk et al. (1976) from the YPF.Ch.PV.es-1 Península de Valdés well, occurs at 719-729 mbsl in a nearly monospecific benthic assemblage without planktonic forms. This horizon overlies Late Danian beds and was originally dated as Eocene (Masiuk et al., 1976). Malumián (1993) identified the specimens as belonging to $B$. paleocenica sp. nov. here described, and assigned the horizon to the Danian, based on correlation with the outcrops of the Neuquén Basin.

Boltovskoyella argentinensis and $B$. patagonica are known from the Middle-Late Eocene of the Austral Basin, from both Chilean and Argentine localities. In Argentina, B. patagonica was recorded from the following localities:

(a) Its type locality, SC-1 well, 630 mbsl (type sample) and 571-578 mbsl. Specimens were also recorded in thin sections from $550-562 \mathrm{mbsl}$. The beds containing $B$. patagonica were dated as Oligocene, probably Early Oligocene (Malumián et al., 1971). They lack planktonic microfossils, but horizons at $648-658 \mathrm{mbsl}$ were assigned to the Globigerapsis index index and Globorotalia inconspicua inconspicua Zones of Jenkins (1966), based on the occurrence of Globigerinatheka index (Finlay), Subbotina sp. cf. S. linaperta (Finlay) and Truncorotaloides collactea (Finlay) (Malumián et al., 1971). Uphole at 251-252 mbsl there is a benthic foraminiferal assemblage of OligoceneEarly Miocene age. The beds containing $B$. patagonica are tentatively included in the Man Aike Formation, of Middle-Late Eocene age (cf. Malumián \& Náñez, 1989; Malumián, 1992, 1994).

(b) Gran Bajo de San Julián, southeast of the Laguna del Carbón, at the base of the outcropping Palaeogene succession (Malumián \& Náñez, 1989; Náñez, 1990). The beds containing $B$. patagonica, tentatively included in the Man Aike Formation, underlie beds of the San Julián Formation dated as latest Eocene-earliest Oligocene (P17 Zone of Blow, 1969), by means of planktonic foraminifers (Bertels, 1975). The whole foraminiferal assemblage from the Man Aike Formation at this locality is very similar to that of the SC-1 well at $630 \mathrm{mbsl}$.

(c) SEC-7 well, 114 and 117 mbsl, Man Aike Formation. Identification of the fragmentary, very scarce specimens, is tentative (Malumián, 1992). They occur associated with Testacarinata inconspicua (Howe) and T. aculeata (Jenkins), which range from the Globigerinatheka index Zone to the Testacarinata inconspicua Zone (Late Middle to Early Late Eocene; Jenkins, 1985), or from the P11 to P14 Zones (Blow, 1979). Some of the associated benthic foraminifera are common to the La Despedida Formation, of Middle-Late Eocene age (Malumián, 1992).
Calcareous nannoplankton correspond to NP15-NP18 Zones (Concheyro, 1991).

(d) Very scarce, fragmentary specimens referred to Boltovskoyella? sp. from the CB. es-6 Campo Bola well, 594-604 and 654-664 mbsl, Man Aike Formation (Náñez, 1990), probably correspond to $B$. patagonica.

(e) Specimens referred to $B$. patagonica by Malumián \& Náñez (1989), from the upper member of the La Despedida Formation are here identified as $B$. sp. cf. $B$. patagonica. The specimens occur in the Cribrorotalia $\mathrm{cf}$. tainuia assemblage, of Middle-Late Eocene, probably Late Eocene age, based on its benthic and planktonic foraminifera, the latter characterised by Globigerinatheka index index, Subbotina linaperta and S. angiporoides (Hornibrook) with transitional forms to $S$. angiporoides minima (Jenkins), (Malumián, 1989).

In Argentina, Boltovskoyella argentinensis was recorded from two localities:

(a) Its type locality, LA. x-1 La Aurora well, 645-655 mbsl and 665-675 mbsl (type sample). Malumián \& Masiuk (1972) assigned these horizons a late Eocene age, based on correlation with the SC-3 well, also in the Austral Basin. They are tentatively included here in the Man Aike Formation, of Middle-Late Eocene age.

(b) Río Turbio coal measures area. The specimens come from the upper member of the Río Turbio Formation, from both below and above the coal seams. The section below the coal seams was assigned a Late Middle to Early Late Eocene age, based on the occurrence of Testacarinata inconspicua, and to the NP16 Zone of Martini (1971), Middle Eocene, based on the abundance of Chiasmolithus modestus Perch-Nielsen. The section above the coal seams lacks planktonic foraminifera and calcareous nannoplankton, their age being considered the same as the levels below the coal seam or slightly younger (Carrizo et al., 1990).

In Chile, $B$. argentinensis was identified as Patelinella inconspicua by Cañón (fide Malumián \& Náñez, 1989) in the Puerto Nuevo Formation, who highlighted its character as a guide species. Malumián \& Náñez (1989) mentioned its association with Subbotina angiporoides minima and Globigerinatheka index. Martínez-Pardo \& Martínez-Guzmán (1989) assigned to Boltovskoyella a post Oligocene, probably EarlyMiddle Miocene age, for the Chilean area of the Austral Basin, and mentioned that $B$. patagonica and $B$. argentinensis co-occur in surface samples and may be conspecific.

However, Hrómic (1990) recognized Boltovskoyella in the Puerto Nuevo and Santa Clara Formations (Tierra del Fuego Island, Chile), which correspond to the earliest part of the Miradorian Stage (Natland et al., 1974). The base of the Miradorian Stage is Late Eocene and the upper part Early Oligocene, according to its calcareous nannoplankton (Mobil Oil, fide Hrómic, 1990). In the Vulcano no. 1 well, B. patagonica is associated with Globigerinatheka index. In the Ciaike no. 1 well, both $B$. patagonica and $B$. argentinensis are associated with $S$. angiporoides minima. In this well, $B$. argentinensis has in part 


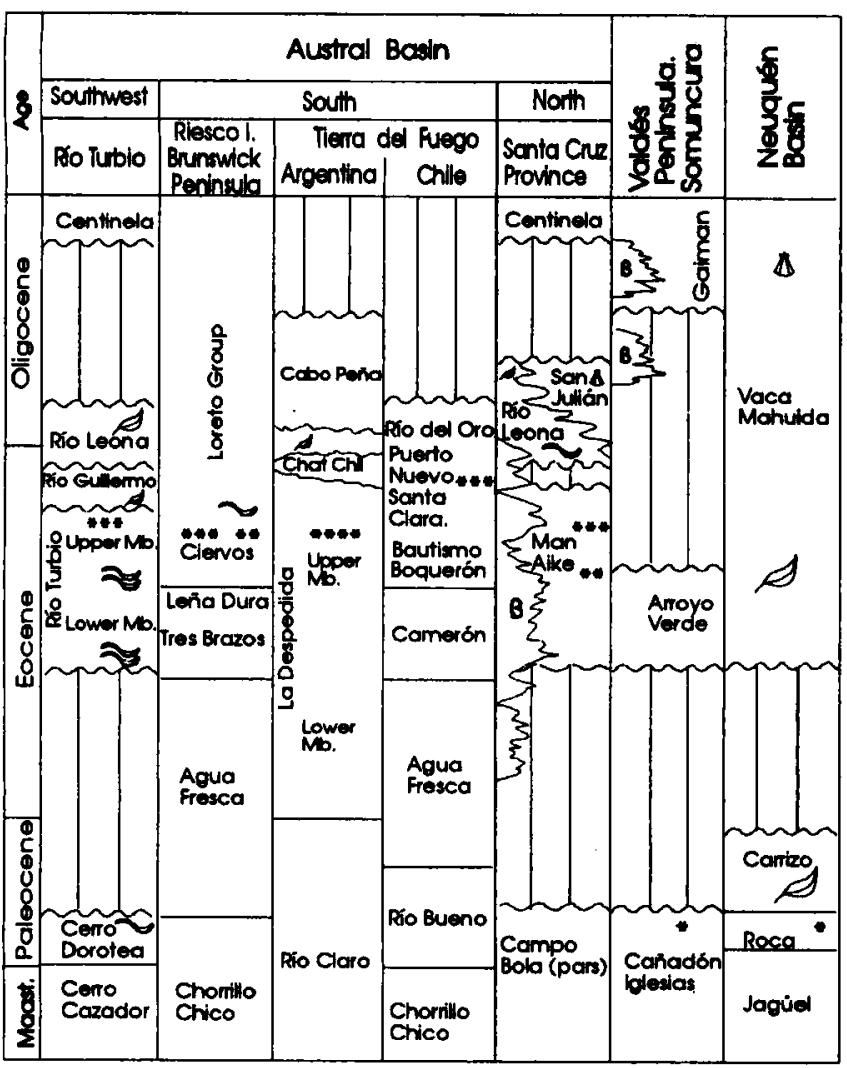

LEGEND

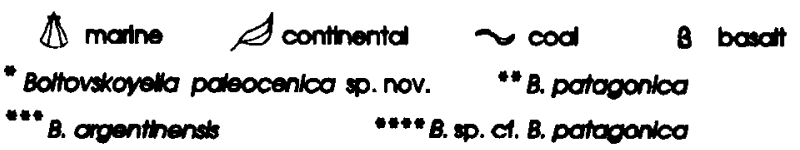

Fig. 2. Stratigraphic chart (modified from Malumián \& Náñez, 1996) and distribution of Boltovskoyella spp. in Patagonia. Units are marine formations unless otherwise stated.

a higher stratigraphical range than $B$. patagonica (Hrómic, 1990). This record clarifies the stratigraphical relationship between the two species, suggesting that $B$. argentinensis survived $B$. patagonica.

In summary, Boltovskoyella is recorded from the Danian and the Middle-Late Eocene (Fig. 2). The lack of record in the Late Palaeocene-Early Eocene may be related to the fact that marine sediments of this age are very scarce and palaeoecologically unsuitable for the genus. On the other hand, despite the large number of samples and localities studied from the Maastrichtian of the Neuquén-Colorado Basin, some of them of a very shallow setting, Boltovskoyella was not recorded (cf. Malumián et al., 1995), although other asterigerinatids occur.

\section{PALAEOECOLOGY}

Boltovskoyella paleocenica sp. nov. comes from the Neuquén Basin, which for the Latest Cretaceous-Early Palaeogene has been compared to the Persian Gulf (Barrio, 1990a,b, 1991), because of its shape and the arid climate indicators, evaporites and caliche (Ramos, 1981). At the Puesto sin Nombre section, $B$. paleocenica sp. nov. occurs in calcareous mudstones, interbedded with oyster coquinas and beds penetrated by numerous Thalassinoides burrows. The mudstones contain frequent Ostreinae, shell debris, mainly of bivalves and echinoids, Callianassa and crab remains (Náñez \& Concheyro, 1997). The foraminiferal assemblage is of low diversity, with few planktonic forms. The highest abundance of $B$. paleocenica sp. nov. occurs in sample PSN 58 (Fig. 3), which besides foraminifera, contains abundant ostracods and echinoid spines, some bryozoa and fish scales. Of more than 2000 benthic foraminifera specimens from the fraction $>125 \mu \mathrm{m}$, the more abundant species are: $B$. paleocenica sp. nov., 57\%, 'Protelphidium' cf. $P$. hofkeri Haynes, 24\%, Miliolids ( $Q$ uinqueloculina sp., Spiroloculina sp.), 10\%, Polymorphina frondea (Cushman), 6\%. Planktonic forms constitute less than one percent of the assemblage.

At the Cerros Bayos section, B. paleocenica sp. nov. was found in several samples (Fig. 3). The sequence stratigraphy and depositional setting of this section were analyzed by Casadio \& Concheyro (1992), who indicated shallow-water conditions during the Danian, from inner shelf to tidal, estuarine and lagoon environments. Samples 2-1, 6-1 and 7-1 are calcareous mudstones, interbedded with $20-30 \mathrm{~cm}$ thick grading upwards bioclastic floatstones, deposited in a shallow sea. These mudstones contain bivalves, crustacea and gasteropoda; among others: Arca sp., Pinna sp., Callianassa sp., Xanthilites gerthi (Glaessner) and Turritella sp. (Casadio \& Concheyro, 1992). In sample 6-1 the most common benthic foraminifers are Anomalinoides acuta (Plummer), Gavelinella midwayensis (Plummer) and $B$. paleocenica sp. nov. Planktonic tests are more abundant in these samples than in those from the Puesto sin Nombre section. Sample 13-1 corresponds to a facies of packstones and oolitic grainstones with scarce bioclasts, deposited under very shallow subtidal conditions, and interpreted as lagoon deposits. The foraminiferal assemblage is of very low diversity, virtually without planktonic forms, 'Protelphidium' cf. $P$. hofkeri is dominant, with minor $B$. paleocenica sp. nov. Sample 15-1 is from a biostrome composed of the mollusc Cubitostrea ameghinoi (Ihering), in a subtidal setting. It yielded a rather poor assemblage, with common $B$. paleocenica sp. nov., miliolids and polymorphinids.

In the Península de Valdés well, the specimens which probably belong to $\boldsymbol{B}$. paleocenica sp. nov., come from a dolomite and are associated with abundant bryozoa. These horizons correspond to the shallowest palaeodepth recorded for the Latest Cretaceous-Cenozoic succession in this well (Masiuk et al., 1976).

Boltovskoyella paleocenica sp. nov. was recorded from only very shallow, restricted environments, despite the high number of samples studied from more open marine Danian sediments. Its occurrence in carbonate lithologies, including oolites, suggests a preference for relatively warm-water settings.

In the SC-1 well, $B$. patagonica occurs in a low diversity assemblage, associated with abundant miliolids at $571-578 \mathrm{mbsl}$ (Malumián et al., 1971), which would correspond to an inner shelf, restricted environment, of probably hypersaline waters. Records from the Man Aike Formation at the SEC-7 and CB.es6 wells, and from the upper member of the La Despedida Formation also correspond with shallow-water environments.

Boltovskoyella argentinensis is the dominant species in its type 
OPASO

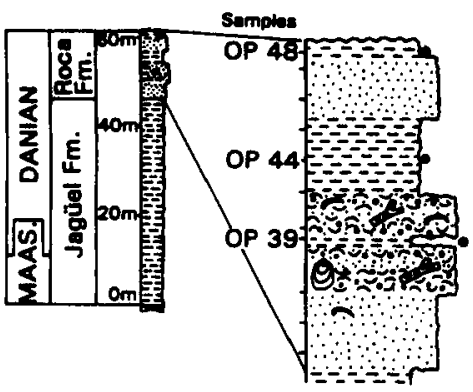

BAJADA DEL JAGÜEL

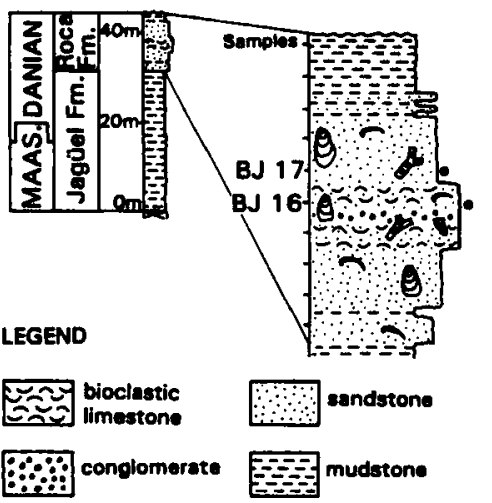

PUESTO SIN NOMBRE

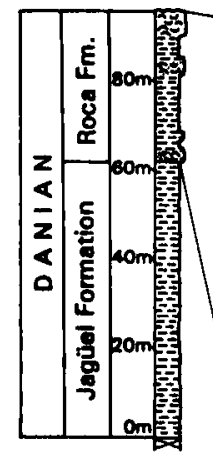

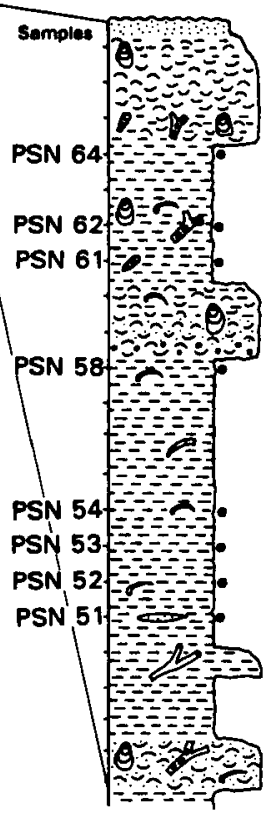

\section{CERROS BAYOS}
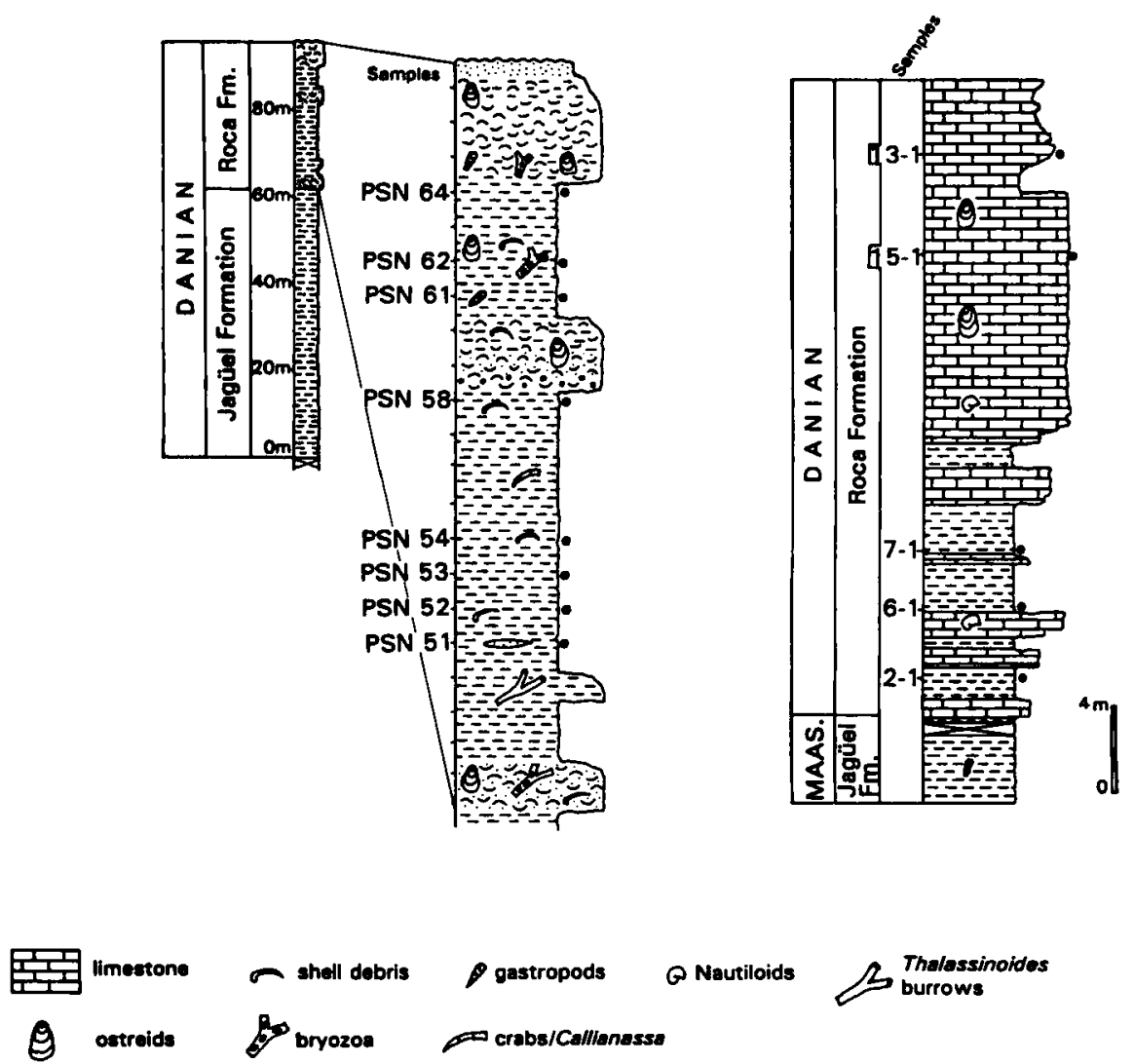

Fig. 3. Stratigraphic columns of the Opaso, Bajada del Jagüel and Puesto sin Nombre sections (modified from Náñez \& Concheyro, 1997) and from Cerros Bayos section (modified from Casadío \& Concheyro, 1992). Dark points indicate position of samples containing Boltovskoyella paleocenica sp. nov.

sample (Malumián \& Masiuk, 1972). In the Río Turbio Formation, in the D-60 well, it occurs in a very low diversity assemblage, the dominant species being Elphidium rioturbiense Malumián, with $B$. argentinensis the second most abundant (Malumián, 1994). This assemblage corresponds to a very shallow environment, of probably hyposaline waters. Boltovskoyella argentinensis also has been recorded, with few specimens, from open marine settings, such as that of the Puerto Nuevo Formation.

The occurrence of Boltovskoyella spp. as dominant in marginal environments and scarce in open marine ones suggests an opportunistic character (Levinton, 1970). Also, they seem to have inhabited hyposaline to hypersaline waters. Their preference for temperate-warm waters is supported by the occurrence in carbonate, even oolitic settings in the Neuquén and Península de Valdés Basins, the occurrence in a coal-bearing unit, such as the Río Turbio Formation, and by association with discoasters in the Man Aike Formation (Concheyro, 1991).

The planoconvex, high trochospiral test, coarsely perforate on the spiral side and imperforate on the umbilical side, suggests that the life habitat of Boltovskoyella was epifaunal (cf. Corliss \& Chen, 1988).

\section{PALAEOBIOGEOGRAPHY}

Boltovskoyella argentinensis, B. patagonica, B. sp. cf. $B$. patagonica and $B$. paleocenica sp. nov. seem to be restricted to Patagonia. Since Heminwayina zealandica is not considered a Boltovskoyella, the genus remains endemic to Patagonia. Boltovskoyella argentinensis and $B$. patagonica occur in the assemblage of highest degree of endemism of the Cenozoic of Patagonia, which developed during the Middle-Late Eocene. The relationship between New Zealand and Patagonia MiddleLate Eocene foraminiferal assemblages is believed to be less close than was thought before (Malumián, 1994) and the restriction of Boltovskoyella to Patagonia weakens it even more. However, links remain, by genera such as Cribrorotalia, Notorotalia, Antarcticella and Nummodiscorbis.

Boltovskoyella paleocenica sp. nov. seems to be one of the few Danian species endemic to Patagonia. The Danian foraminiferal assemblage of this region has been regarded as cosmopolitan, of Midway type (Berggren \& Aubert, 1975), corresponding mostly to an inner-middle shelf environment (Malumián, 1979). According to Malumián \& Caramés (1995), it has only three frequent endemic species, Buliminella ex gr. B. isabelleana Camacho, Lagenoglandulina neuquensis (Bertels) and Favolagena 


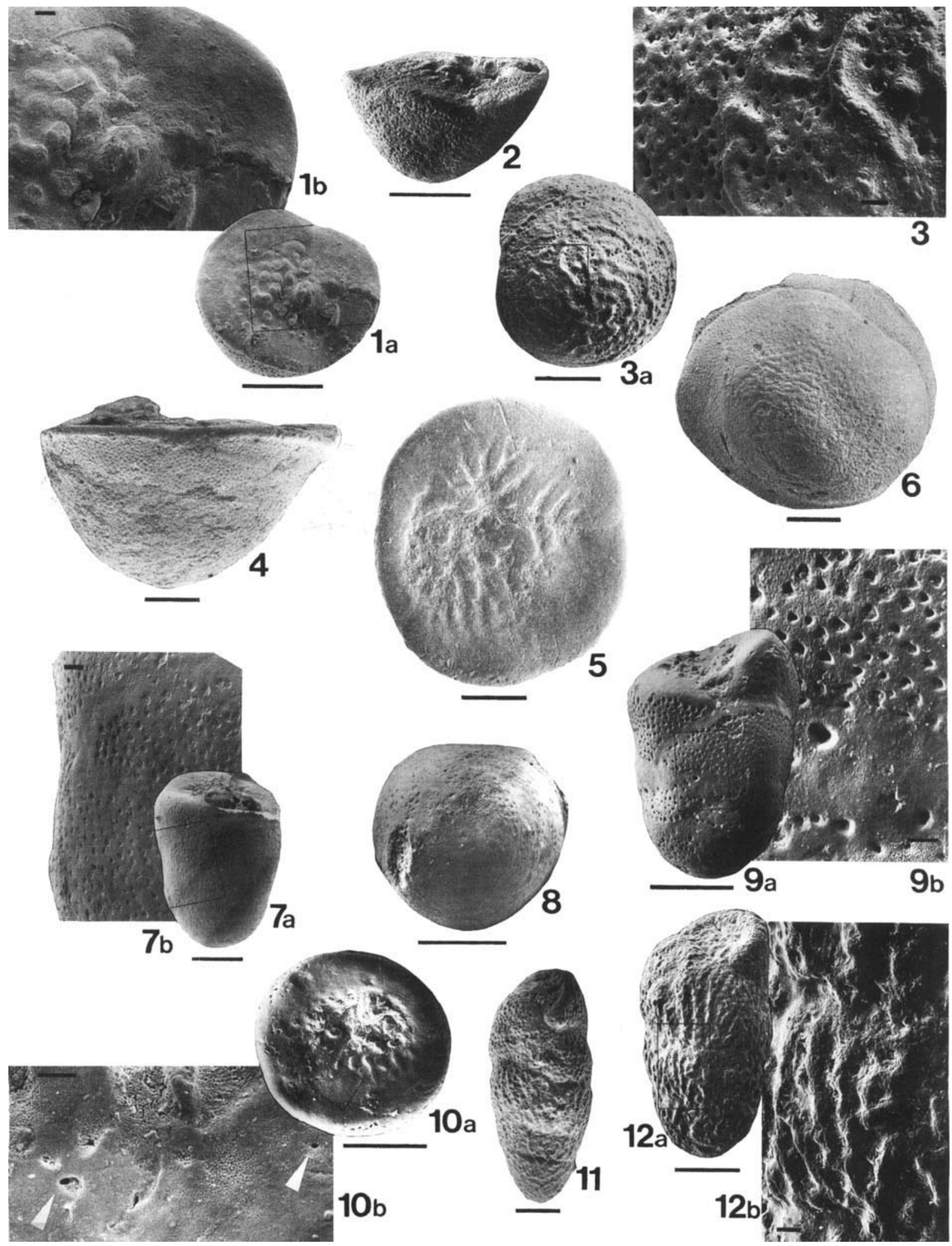

Plate 1 

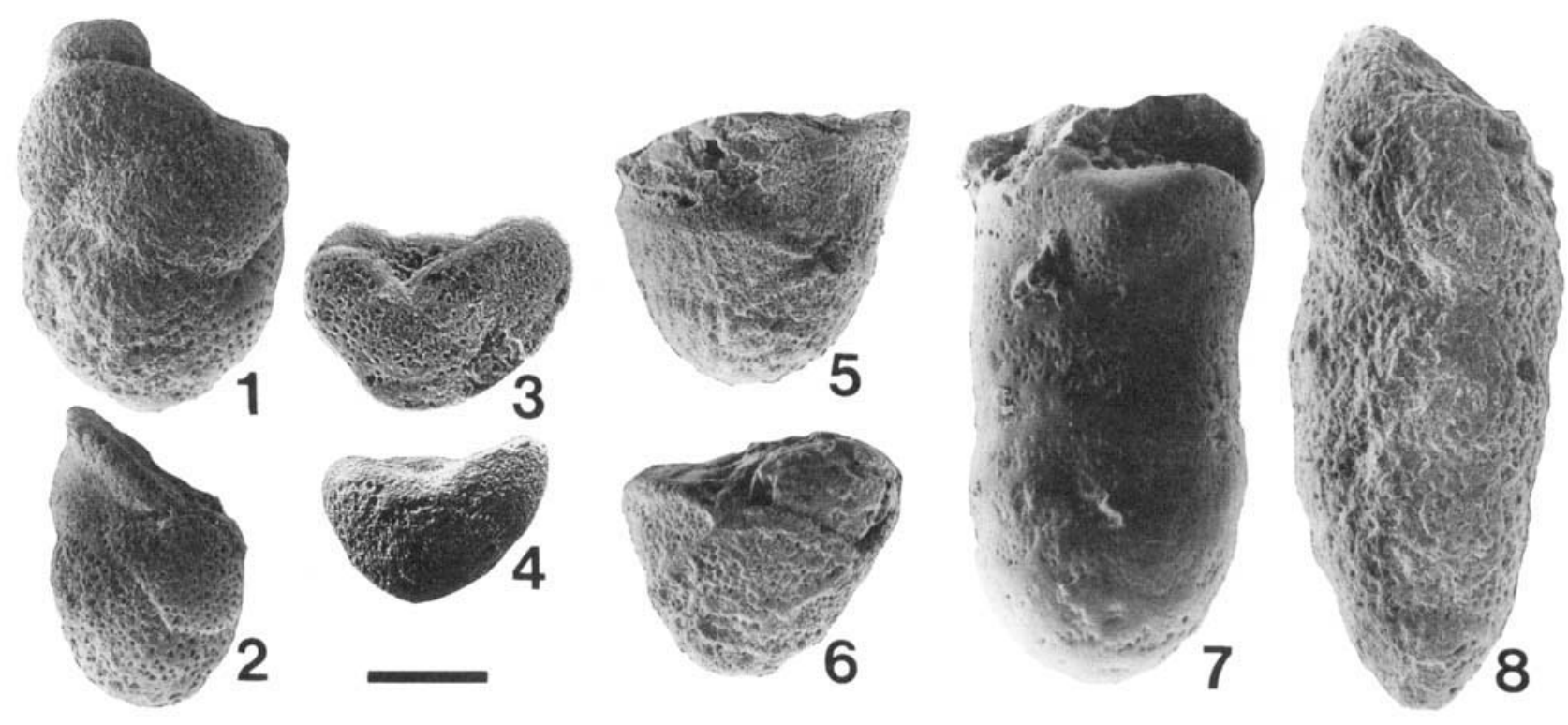

Fig. 4. Scale bar $=100 \mu \mathrm{m}$. figs 1-2. Boltovskoyella paleocenica sp. nov.. Uncommon, very high specimens, showing a tendency to form elongate, parallel-sided tests. Danian, Neuquén Basin, Roca Formation, Puesto Sin Nombre Section, sample PSN 58. SGN 1901-1902. figs 3-8. Tendency to elongation and reduction in the number of chambers per whorl through time. figs 3, 4. Boltovskoyella paleocenica sp. nov., Danian, Neuquén Basin, Roca Formation. fig. 3, Holotype. fig. 4, Same specimen as Pl. 3, fig. 10. figs 5, 6. Boltovskoyella patagonica Malumián \& Masiuk. Middle-Late Eocene, Austral Basin, Man Aike Formation, SC-1 well, 630mbsl. SGN 1903-1904. figs 7, 8. Boltovskoyella argentinensis Malumián \& Masiuk. Middle-Late Eocene, Austral Basin. SGN 1905-1906. fig. 7, Man Aike? Formation, LA. x-1 La Aurora well, 665-675 mbsl. fig. 8, form from the Río Turbio Formation, Upper Member, probably the youngest of the lineage, showing a more elongate test with tendency to biseriality and uncoiling. D60 well, 577 mbsl.

atilai (Bertels). This situation contrasts with the marked endemism of the foraminiferal assemblages from the Maastrichtian of northern Patagonia (Malumián et al., 1995) and the moderate endemism in the Middle-Late Eocene (Malumián, 1994). Strong palaeoaustral (cool-temperate) benthic faunal affinities were noted for Late Cretaceous-Early Eocene times along the South Pacific margin (Fleming, 1962; Stevens, 1973, 1980). Based on molluscan faunas, Zinsmeister (1979) proposed the name Weddellian province for a shallow-water region extending from southeast Australia to southern South America. According to Casadio (1994), the molluscan faunas from the Maastrichtian of the Neuquén Basin have a strong affinity with those from the Weddellian province, but in the Early Danian they were succeeded by subtropical forms.

In contrast with the normal marine foraminiferal assemblages, those from the very shallow, marginal environments from the Danian of Patagonia appear to be dominated by or have a high endemic content. Malumián \& Caramés (1995) indicated that Buliminella isabelleana is one of the endemic species of more palaeogeographic significance, due both to its frequency and abundance. It frequently occurs in monospecific or high dominance assemblages in extreme, shallow, stressed environments. Boltovskoyella paleocenica sp. nov., apparently restricted to northern Patagonia, also dominates or is an important element of shallow assemblages. Thus, two foraminiferal assemblages of marginal marine affinity may be differentiated in the Danian of Patagonia: one, rather widely distributed, dominated by $B$. isabelleana, of infaunal, detritivorous habit (Malumián \& Caramés, 1995), probably developed on soft, organic-rich bottoms. The other, more restricted, dominated by

Explanation of Plate 1 Boltovskoyella spp. from the Middle-Late Eocene of the Austral Basin, Argentina. SGN 1769-1780. Scale bar $=100 \mu \mathrm{m}$, unless otherwise stated.

figs 1-3. Boltovskoyella patagonica Malumián \& Masiuk, from the Man Aike Formation. fig. 1. Umbilical view showing nodes and imperforate wall. SC-1 well, 571-578 mbsl. Scale bar fig. $1(\mathrm{~b})=10 \mu \mathrm{m}$. fig. 2 . Side view showing medium high trochospiral test and angular periphery. SC-1 well, $571-$ $578 \mathrm{mbsl}$. fig. 3. Spiral view, showing raised sutures and coarse perforations. SC-1 well, $630 \mathrm{mbsl}$. Topotype. Scale bar fig. $3(\mathrm{~b})=10 \mu \mathrm{m}$. figs $4-6$. Boltovskoyella sp. cf. B. patagonica Malumián \& Masiuk, from the La Despedida Formation, Upper Member. A medium to high trochospiral species, with angular periphery, 3 chambers in the last whorl, and umbilical surface with grooves and nodes. Section near La Aurelia Farm, Tierra del Fuego Island, $540 \mathrm{~m}$ above base. figs 7-12. Boltovskoyella argentinensis Malumián \& Masiuk. figs 7-10. The type species of the genus, characterized by its high trochospiral, nearly parallel-sided test. Spiral side is very coarsely and regularly perforate. Umbilical side is imperforate in numerous specimens studied under SEM, except for specimen of fig. 10, with occasional perforations (shown in fig. 10b). Man Aike? Formation. LA. x-1 La Aurora well, 665-675 mbsl. Topotypes. Scale bar figs 7(b), $9(\mathrm{~b}), 10(\mathrm{~b})=10 \mu \mathrm{m}$. figs 11-12. Specimens from the Rio Turbio Formation, Upper Member, which have a more elongated test, coarser ornamentation and are subtriangular rather than subcircular in section, in comparison with topotypes. D-60 well, 577 mbsl. Scale bar fig. $12=10 \mu \mathrm{m}$. 

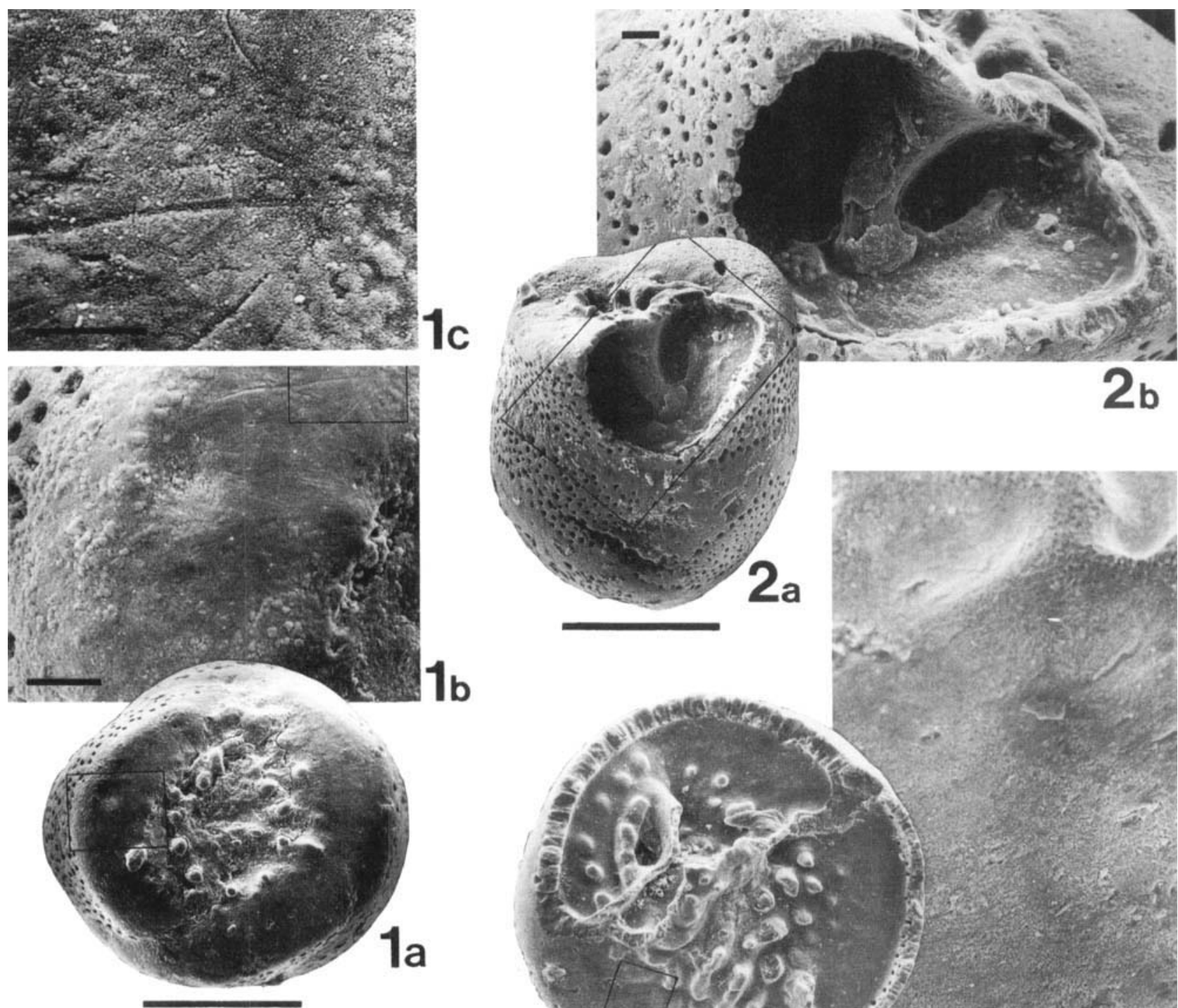

$1 b$
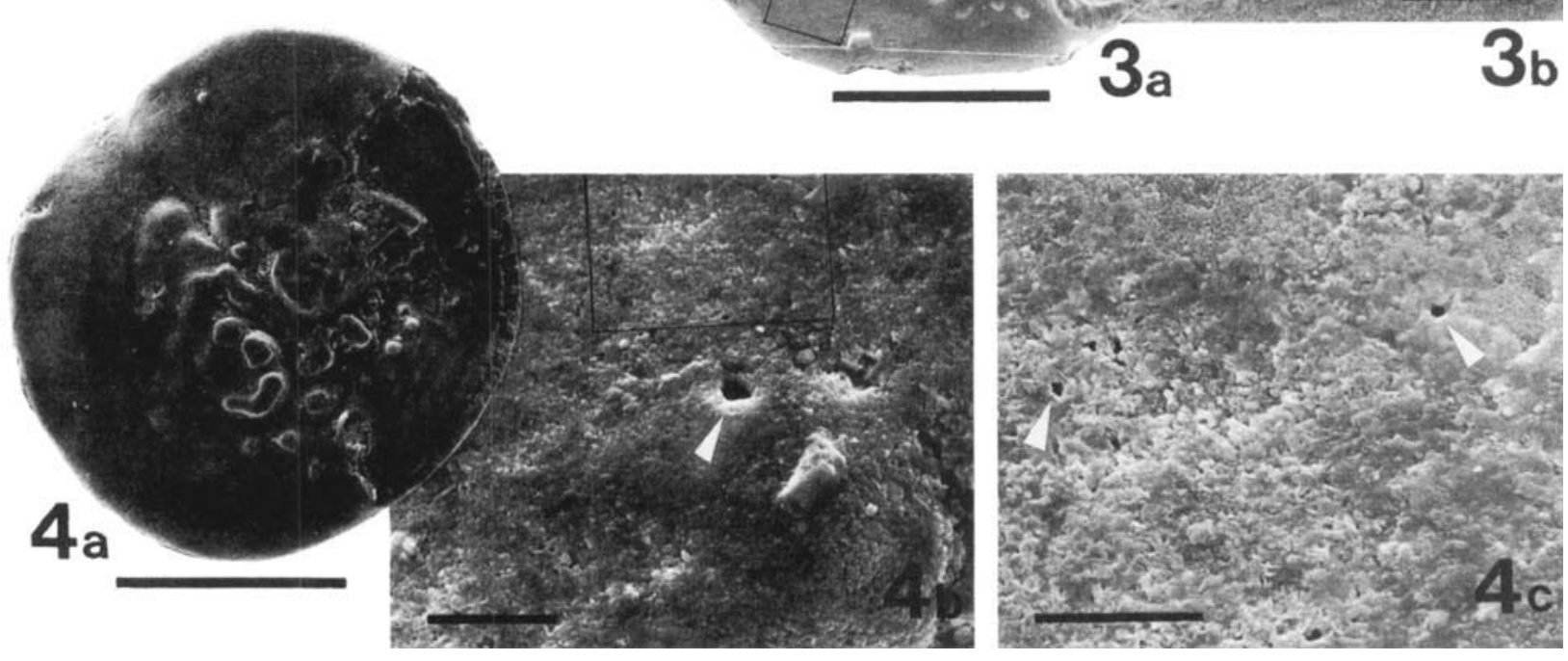

Plate 2 
B. paleocenica sp. nov., of epifaunal habit, corresponds to relatively warm-water, carbonate settings, probably on harder or sandy bottoms.

Boltovskoyella has not been found in the Palaeocene of Antarctica (cf. Huber, 1988), probably because of the higher latitude.

\section{SYSTEMATIC DESCRIPTIONS}

Synonymy is restricted to papers where species are figured. Illustrated specimens are deposited in the Micropalaeontological Collection of the Dirección Nacional del Servicio Geológico, Buenos Aires, Argentina, catalogue numbers SGN 1741, 1769 to 1792 and 1899 to 1906.

Suborder Rotaliina Delage \& Hérouard, 1896

Superfamily Asterigerinacea d'Orbigny, 1839

Family Asterigerinatidae Reiss, 1963

Genus Boltovskoyella Malumián \& Masiuk, 1972

Remarks: Malumián \& Masiuk (1972) differentiated Boltovskoyella from other genera mainly by its conical test, with a high dorsal side and imperforate ventral side with supplementary chambers. The unique character of Boltovskoyella among the Asterigerinatidae was pointed out by Loeblich \& Tappan (1987), due to its very high spire forming a parallel-sided cone and its broad umbilicus; they indicated that the systematic position of the genus needs additional study. Other feature of Boltovskoyel$l a$ is the very coarsely perforate spiral side, in contrast with the imperforate umbilical side. The type species of Eoeponidella, $E$. linki Wickenden, is uniformly perforate on both spiral and umbilical sides and has a lower trochospiral test (see illustrations of McDougall, 1987 and Loeblich \& Tappan, 1987). Asterigerinata has a low trochospiral test, with coarse pores on the supplementary chamberlets; few pores also seem to occur on the umbilical side of the main chambers, according to observation under light microscope of topotypes of $A$. dominicana Bermúdez, type species of Asterigerinata. Biasterigerina differs by having a densely perforate umbilical side, with very narrow and elongate supplementary chamberlets.

None of the eight specimens of Heminwayina zealandica observed (seven from the type sample, kindly sent by $\mathrm{Dr} \mathrm{H}$. Morgans, and one from loc. S168/494 from the Whaingaroan Stage of New Zealand, which was sent by late Dr Hornibrook to Dr Malumián) has a very high spire. One of the topotypes was examined under SEM, showing its umbilical side with coarse pores on part of the main chambers and on the distal part of the supplementary chambers. These features appear to be enough to exclude this species from Boltovskoyella.
Boltovskoyella argentinensis Malumián \& Masiuk, 1972 (Pl. 1, figs 7-12; Pl. 2, figs. 1-3; Fig. 4 (7-8))

1972 Boltovskoyella argentinensis Malumián \& Masiuk: 2, pl. 1, figs 3-6.

Material and localities: Austral Basin, Santa Cruz Province. LA. x-1 La Aurora well, 645-655 mbsl, 65 specimens; 665-675 mbsl (type sample), 60 specimens. D-60 well, Río Turbio area, 573 mbsl, 115 specimens; 574 mbsl, 13 specimens; 577 mbsl, 64 specimens; $579 \mathrm{mbsl}, 1$ specimen. Adaro II well, Río Turbio area, 448.5 masl, 2 specimens.

Remarks: Specimens from the type sample have a very high trochospiral test, subcylindrical in shape, although it may be subconical in few specimens; $5-7$, generally 6 chambers in the first whorl, rapidly reducing to $2-4$, generally 3 chambers in the last whorl; periphery angular to rounded; ovoid to reniform supplementary chambers; surface smooth but with nodes on the umbilical side. Spiral side very coarsely perforate $(2-5 \mu \mathrm{m})$; umbilical side imperforate. Although very few and isolated perforations occur on the umbilical side of one specimen ( $\mathrm{Pl} .1$; fig. 10b), numerous specimens examined under SEM are imperforate (Pl. 2; figs 1-3). No major morphological variation is seen among these specimens, except for the height of the spire (Fig. 4 (7); Pl. 2, fig. 2).

In the Rio Turbio area, $B$. argentinensis was recognized from the upper member of the Río Turbio Formation. Two forms may be differentiated:

(a) Specimens from the Adaro II well, very scarce and not well preserved, are subcylindrical and seem to have a smooth surface, fitting well with topotypes.

(b) Specimens from the D-60 well (Pl. 1; figs 11-12) differ from topotypes by the more elongated test, triangular in section but with rounded angles, a tapering initial end, a stronger tendency to biseriality and uncoiling, having 2-3 chambers in the last whorl, generally $2 \frac{1}{2}$. The wall is always more rugose, with raised interpore walls, sometimes coalescing into longitudinal ridges. However, some specimens show gradational characteristics to topotypes, with rounded base (Pl. 1; fig. 12) or more rounded section.

Specimens from D-60 well are stratigraphically higher than those from the Adaro II well and might belong to a new species, younger than Boltovskoyella argentinensis. For the present, as some gradational characteristics are seen, specimens from the D60 well are included in $B$. argentinensis.

Boltovskoyella patagonica Malumián \& Masiuk, 1972 (Pl. 1, figs 1-3; Pl. 2, fig. 4; Fig. 4 (5-6))

1972 Boltovskoyella patagonica Malumián \& Masiuk: 3, pl. 1, figs $1-2$.

Explanation of Plate 2

Boltovskoyella spp., from the Middle-Late Eocene of the Austral Basin, Argentina. Scale bar $=100 \mu \mathrm{m}$, unless otherwise stated. figs 1-3. Boltovskoyella argentinensis Malumián \& Masiuk, Man Aike? Formation. Fig. 1. Umbilical view of specimen of P1. 1, fig. 9, showing the coarsely perforate spiral side and imperforate umbilical side. Topotype. Scale bar fig. $1(\mathrm{~b})=10 \mu \mathrm{m}$; fig. $1(\mathrm{c})=5 \mu \mathrm{m}$. fig. 2 . Side view of a specimen with part of its last chamber broken off, showing tooth-plate attached to previous foramina. LA. x-1 La Aurora well, 665-675 mbsl. SGN 1899. Scale bar fig. 2(b) $=10 \mu \mathrm{m}$. fig. 3. Umbilical view showing coarse pores on the inner surface of the spiral side, imperforate umbilical side, foramina and broken tooth-plate. SGN 1900. LA. x-1 La Aurora well, 645-655 mbsl. Scale bar fig. 3(b) $=10 \mu \mathrm{m}$. fig. 4. Boltovskoyella patagonica Malumián \& Masiuk. Umbilical view showing a perforation on the last supplementary chamber (boring?) and small holes (most of them due to dissolution). Same specimen as Pl. 1, fig. 1. Scale bar fig. $4(\mathrm{~b})=10 \mu \mathrm{m}$; fig. $4(\mathrm{c})=5 \mu \mathrm{m}$. 

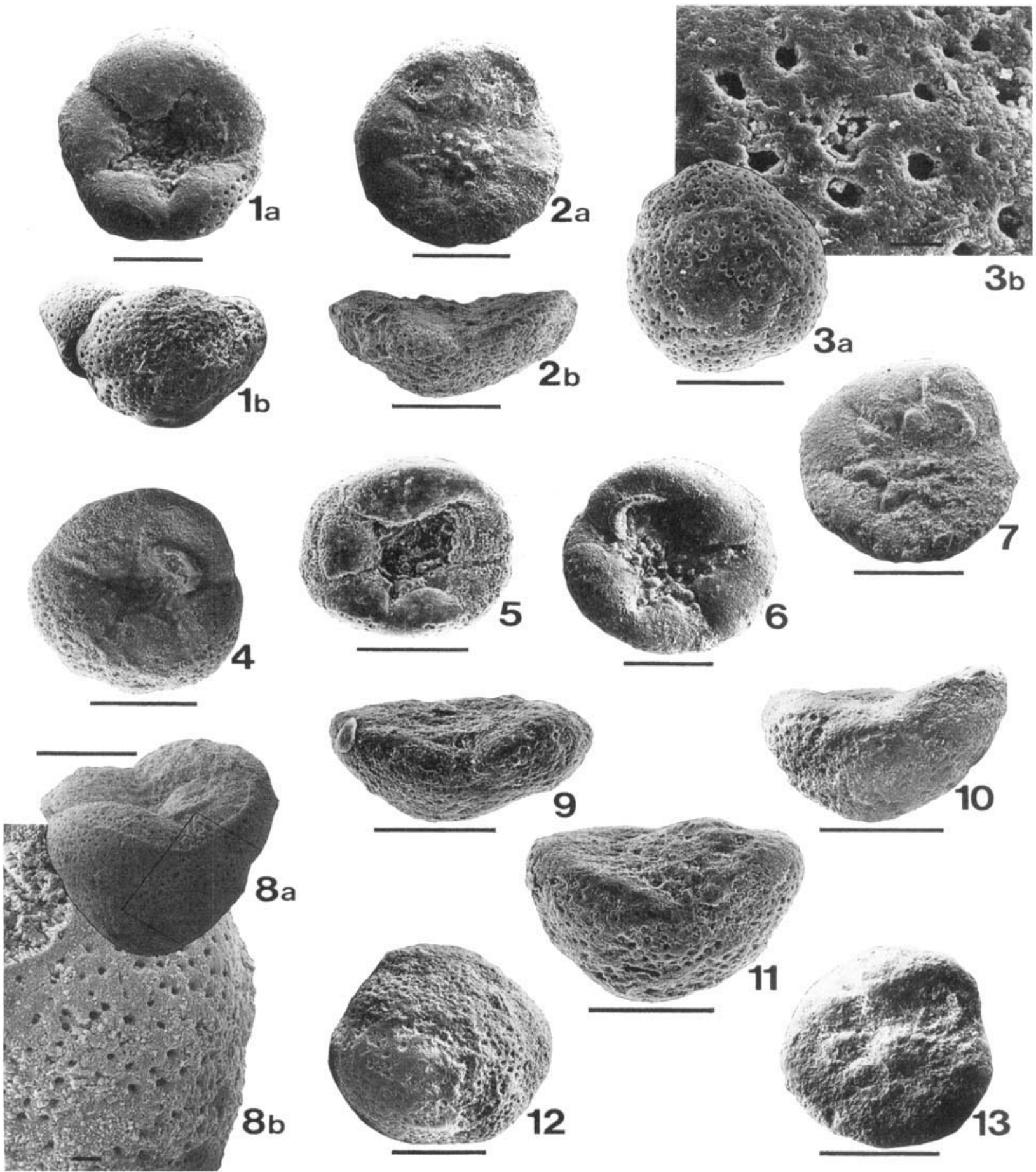

Explanation of Plate 3 Boltovskoyella paleocenica sp. nov., from the Danian of the Neuquén Basin, Argentina, Roca Formation. figs 1(a,b), holotype (SGN 1781); figs 2-13, paratypes (SGN 1741; 1782-1792). Scale bar $=100 \mu \mathrm{m}$, unless otherwise stated. figs 1-8. Puesto sin Nombre Section (PSN). fig. 1. Holotype. Umbilical and side views, showing the moderately high trochospiral test, rounded periphery and imperforate, depressed umbilical side, with collapsed supplementary chambers covered with nodes. Sample PSN 58. fig. 2. Low trochospiral, probably juvenile specimen, with angular periphery and umbilical plug covered with nodes. Sample PSN 52. fig. 3. Spiral view showing coarse perforations. Sample PSN 58. Scale bar fig. $3(\mathrm{~b})=10 \mu \mathrm{m}$. fig. 4. Umbilical view showing foramina with attachment of tooth-plate. Sample PSN 58. fig. 5. Umbilical view showing open, wide umbilicus left by the collapsed supplementary chambers. Sample PSN 58. fig. 6. Dextral specimen, showing the lip thickened and produced on its distal end. Sample PSN 58. fig. 7. Specimen showing umbilical plug and triangular, elongated supplementary chambers. Sample PSN 62. fig. 8. High trochospiral specimen and detail of coarse perforations on the spiral side. Similar high specimens are rather common. Sample PSN 58 . Scale bar fig. $8(b)=10 \mu \mathrm{m}$. figs 9-13. Cerros Bayos Section, sample M-6. figs 9-11. Specimens showing different degrees of spire height and umbilical side flat to concave. Specimens as high as fig. 8 also occur in the Cerros Bayos section. Specimen of fig. 9 may be a juvenile form. figs $12-13$. Spiral and umbilical views. 
1990 Boltovskoyella patagonica Malumián \& Masiuk; Náñez: pl. 2, figs 14 (a-b).

Material and localities. Austral Basin, Santa Cruz province. SC1 Santa Cruz well, 571-578 mbsl, 25 specimens; $630 \mathrm{mbsl}$ (type sample), 31 specimens. Samples GBO19 and GB1, Gran Bajo de San Julián, southeast of the Laguna del Carbón, at the base of the outcropping Cenozoic succession, 26 specimens.

Remarks. Specimens from the type sample are characterized by the moderately high trochospiral test, subconical in shape, 5-7, generally 6 , chambers in the first whorl, rapidly reducing to $3 \frac{1}{2}-$ 5 , generally $3 \frac{1}{2}-4$ chambers in the final whorl; periphery angular to carinate; ovoid to reniform supplementary chambers; surface on the spiral side with coarse pores $(2-4 \mu \mathrm{m})$ and sutures commonly raised, umbilical surface imperforate, with nodes.

A coarse perforation seen on the last supplementary chamber of specimen of Pl. 2, fig. 4(b) may be a boring, as it does not systematically occur in other chamberlets or specimens. At higher enlargements some small $(c .0 .3 \mu \mathrm{m})$ and irregularly scattered holes are seen; most of them appear to be due to dissolution.

Two fragmentary specimens referred to Boltovskoyella? sp. from the CB.es-6 Campo Bola well, 594-604 mbsl and 654 $664 \mathrm{mbsl}$ (Náñez, 1990), and two fragmentary specimens referred to Boltovskoyella patagonica? from the SEC-7 well, 117 mbsl (Malumián, 1992) may belong to this species. Initial fragments of topotypes of $B$. patagonica and $B$. argentinensis are differentiated by the smoother surface and more thickened sutures of the latter.

One fragmentary specimen referred to as $B$. patagonica from outcrops of the lower member of the Río Turbio Formation (Torre, pers. comm.) seems to be a Cribrorotalia species.

\section{Boltovskoyella sp. cf. B. patagonica Malumián \& Masiuk} (P1. 1, figs 4-6)

Material and locality. Austral Basin, Tierra del Fuego Island, Argentina. Section near La Aurelia farm, La Despedida Formation, upper member. At $540 \mathrm{~m}$ from the base of the section (Malumián, 1989). Five specimens.

Description. Trochospiral test, spiral side moderately high, umbilical side flat to very slightly concave, periphery carinate. Initial part of the spiral side obscured, spiral and intercameral sutures thickened, flush or slightly raised; chambers semilunate in shape, 3-3 $1 / 2$ in the last whorl; sutures on the umbilical side slightly depressed. Aperture interiomarginal, arcuate, with lip. Supplementary chambers obscured by ornamentation on the umbilical surface, but seem to be rather elongate and lobulate. Wall densely perforate on the spiral side, except on the sutures, imperforate on the umbilical side. Umbilical surface with grooves and nodes, the latter concentrated near the aperture.

Remarks. These specimens were referred to as $B$. patagonica by Malumián \& Náñez (1989, p. 257). They differ from $B$. patagonica by being larger, with fewer chambers in the last whorl, more semilunate in shape, supplementary chambers apparently more elongate, and with grooves on the umbilical surface, rather than nodes only.

Asterigerina sp. mentioned from the same sample by Malumián (1989) and Malumián \& Náñez (1989) differs from
Boltovskoyella sp. cf. $B$, patagonica by having a lower test, pores on the lobes of the supplementary chambers, 5-7 chambers in the last whorl, and umbilical surface smoother and with depressed sutures.

\section{Boltovskoyella paleocenica sp. nov.} (P1. 3, figs 1-13; Fig. 4 (1-4))

1964 Rosalina cf. ystadiensis Brotzen; Bertels: 164, pl. 5, fig. 8. 1995 Gen. et sp. indet. 2; Malumián \& Caramés: 103, pl. 2, figs $2-3$.

Derivation of name. Paleocenica, due to its occurrence in the Palaeocene.

Diagnosis. Boltovskoyella with a conical, moderately high trochospiral test, generally 5-6 chambers in the last whorl; triangular supplementary chambers; periphery subangular to broadly rounded and umbilical side flat to concave, frequently with an open, deep umbilicus.

Holotype. SGN 1781, from sample PSN 58, Puesto sin Nombre section, Roca Formation, Late Danian. Illustrated paratypes: SGN 1741, 1782 to 1792 and 1901-02; other paratypes: SGN 1793-1794. Several unfigured specimens are housed at the Cushman Collection of the Smithsonian Institution (Washington). All specimens from the Roca Formation at Puesto sin Nombre and Cerros Bayos sections (Fig. 2).

Material, locality and horizon. More than 1500 specimens from the Puesto sin Nombre section, Añelo Low, Neuquén province, Argentina. Few specimens from the Bajada del Jagüel and Opaso sections, Añelo Low. More than 200 specimens from sample M-6, and few specimens from samples M-2, M-7, M-13 and M-15, Cerros Bayos section, La Pampa province, Argentina. Several specimens from the type section of the Roca Formation, north of General Roca, Río Negro province. Roca Formation, of Early Danian age at the type section and at the Cerros Bayos section, and of Late Danian age at the sections of the Añelo Low.

Description. Trochospiral test, moderately high; subcircular, smooth to moderately lobulate in outline; periphery subangular to broadly rounded. Spiral side strongly convex, $1 \frac{1 / 2-3}{2}$ whorls, generally $2 \frac{1}{2}$, the initial part of the spire frequently obscured by imperforate calcareous material; sutures on the spiral side flush to slightly raised in the initial part of the test, depressed in the last whorl. Umbilical side concave to flat, $31 / 2-61 / 2$, generally $5-6$ chambers in the last whorl; triangular supplementary chambers, more or less elongated, arranged in a stellar pattern; sutures depressed, especially between the last 2-3 chambers. Umbilicus closed, with a plug, to broadly open and deep. Wall coarsely perforate on the spiral side; umbilical side imperforate; supplementary chambers and umbilical plug frequently covered by nodes. Aperture interiomarginal, wide, arcuate, with lip.

Remarks. There is wide variation in the spire height, number and degree of inflation of chambers in the last whorl, elongation of the supplementary chambers, degree of concavity of the umbilical side, and characteristics of the umbilicus. Specimens with a low test, probably juvenile forms, usually have an umbilical plug and subangular periphery (P1. 3; figs 2(a-b)), whereas higher specimens have a broadly rounded periphery and 
a depressed, wide and deep umbilicus, apparently left open by the collapse of the supplementary chambers and plug (Pl. 3; figs $1(a-b), 5)$. Moderately high tests (Pl. 3; figs $1(b), 10)$ are the most abundant; higher tests (PI. 3; fig. 8) are common, whereas the elongate, very high specimens tending to form parallel-sided cones (Fig. 4 (1-2)) are rare. Coiling is mostly sinistral (89\% of 193 specimens from sample M-6, and $68 \%$ of 228 specimens from sample PSN 58). Although regular preservation precludes reliable observation at very high enlargements, umbilical side appears imperforate.

Assignment of this species to the genus Boltovskoyella is due to its high spiral side, which in some specimens tends to form a parallel-sided cone, and its coarsely perforate spiral side, contrasting with the imperforate umbilical side.

Comparisons. It differs from $B$. argentinensis mainly by the shorter, generally conical rather than cylindrical test, and higher number of chambers in the last whorl.

It differs from $B$. patagonica by having more chambers in the last whorl (5-6 rather than generally $3 \frac{1}{2}$ ), a more rounded periphery, higher and more inflated chambers, and triangular supplementary chambers.

Type material of Asterigerina primaria Plummer, from the Palaeocene of the Gulf Coastal Plain was kindly sent by Dr G. Buckley for comparison (slide 33101 of the Plummer collection housed at the Field Museum of Natural History, Chicago). The slide contains four specimens from station 67 , one of them matching very well to that illustrated by Plummer (1927). They have a more lenticular test, the umbilical side flat to slightly convex, an acute, keeled periphery and bigger and less elongated supplementary chambers. There are pores on the last supplementary chamber of one specimen, although a SEM photograph would be needed to be sure. Asterigerina primaria is known from the Palaeocene of the Gulf Coast, Denmark and SW France (Berggren \& Aubert, 1975).

Boltovskoyella paleocenica sp. nov. differs from Eoeponidella linki Wickenden, from the Upper Cretaceous of Canada, by the generally higher and more conical test and imperforate umbilical side.

Boltovskoyella seems to have a tendency to elongation and reduction in the number of chambers per whorl, similar to that mentioned by Revets (1987) for other lineages of trochospiral foraminifera. $B$. paleocenica, from the Danian, is relatively short and has the highest number of chambers in the last whorl (5-6).

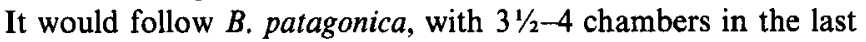
whorl (Pl. 1; fig. 1(a)); later typical forms of $B$. argentinensis, with 3 chambers (Pl. 1; fig. 10(a)), and finally the form illustrated from the Rio Turbio area (Pl. 1; fig. 11), which clearly tends to biseriality and is even more elongate than typical $B$. argentinensis.

\section{ACKNOWLEDGEMENTS}

The Dirección Nacional del Servicio Geológico, Argentina, granted permission to publish this paper. I thank S. Casadio (Universidad Nacional de La Pampa, Argentina) for the samples from the Cerros Bayos section, and N. Malumián (Dirección Nacional del Servicio Geológico, Argentina) for the valuable material provided for this study, including topotypes of $B$. argentinensis and $B$. patagonica, and specimens from Rio Turbio and Tierra del Fuego Island; also he critically read several drafts. I am grateful to G. Buckley (Field Museum of Natural History, Chicago) for the loan of type specimens of Asterigerina primaria and to $\mathbf{H}$. Morgans (Institute of Geological and Nuclear Sciences, Lower Hutt) for the loan and donation of topotypes of Heminwayina zealandica. I also thank P. Quilty (Australian Antarctic Division, Kingston) and H. Morgans for critically reading a draft and improving the language, and $W$. Berggren (Woods Hole Oceanographic Institution) and B. Huber (Smithsonian Institution) for comparison of specimens of $B$. paleocenica sp. nov. This paper is a contribution to IGCP Project 301 'Paleogene of South America'.

\section{Manuscript received March 1996 Manuscript accepted January 1997}

\section{REFERENCES}

Ardolino, A., Franchi, M. \& Fauqué, L. 1995. Carta geológica de la Provincia del Neuquén. Departamento Añelo. Servicio Geológico Neuquino, Zapala y Dirección Nacional del Servicio Geológico, Buenos Aires.

Ardolino, A. \& Franchi, M. 1997. Estratigrafia. In Ardolino, A. \& Franchi, M. (Eds), Geológia y Recursos Minerales del Departamento Añelo. Provincia del Neuquén. Republica Argentina. Dirección Provincial de Minería, Boletín, 3 \& Dirección Nacional del Servicio Geológico, Anales, Vol. 25, 9-106. Buenos Aires.

Barrio, C. A. 1990a. Late Cretaceous-Early Tertiary sedimentation in a semi-arid foreland basin (Neuquén Basin, western Argentina). Sedimentary Geology, 66: 255-275.

Barrio, C. A. 1990b. Paleogeographic control of Upper Cretaceous tidal deposits, Neuquén Basin, Argentina. Journal of South American Earth Sciences, 3: 31-49.

Barrio, C. A. 1991. Controles en la sedimentación de cuencas foreland. El ejemplo del Grupo Malargüe (Campaniano-Paleoceno) en la cuenca Neuquina, Argentina. $6^{\circ}$ Congreso Geológico Chileno, Resúmenes expandidos, 597-601. Santiago de Chile.

Berggren, W. A. \& Aubert, J. 1975. Paleocene benthonic foraminiferal biostratigraphy and paleoecology of Atlantic-Tethyan regions: Midway-type fauna. Palaeogeography, Palaeoclimatology, Palaeoecology, 18: $73-192$.

Bertels, A. 1964. Micropaleontología del Paleoceno de General Roca (Provincia de Río Negro). Revista del Museo de La Plata, (Nueva Serie), Paleontología, 4: 125-184.

Bertels, A. 1975. Bioestratigrafia del Paleógeno en la República Argentina. Revista Española de Micropaleontologia, 7: 429-50.

Bertels, A. 1980. Estratigrafía y foraminíferos (Protozoa) bentónicos del límite Cretácico-Terciárico en el área tipo de la Formación Jagüel, provincia del Neuquén, República Argentina. Segundo Congreso Argentino de Paleontología y Bioestratigrafía y Primer Congreso Latinoamericano de Paleontologia, Actas, Vol. 2, 47-91. Buenos Aires.

Blow, W. H. 1969. Late middle Eocene to Recent planktonic foraminiferal biostratigraphy. In Brönnimann, P. \& Renz, H.H. (Eds), Proceedings of the First International Conference on Planktonic Microfossils, 199-422. E. J.Brill, Leiden.

Blow, W. H. 1979. The Cainozoic Globigerinida, 1413 pp. E. J. Brill, Leiden.

Carrizo, R., Malumián, N., Náñez, C., Caramés, A. \& Concheyro, A. 1990. Micropaleontología y correlación del Terciario del área carbonífera de Río Turbio, Provincia de Santa Cruz, Argentina. Segundo Simposio sobre el Terciario de Chile. Procesos y Productos de Depositación en el ámbito andino, Actas, 29-50. Concepción.

Casadio, S. 1994. Cambios en la malacofauna marina durante la 
transición Cretácico-Terciaria en el Norte de la Patagonia. VI Congreso Argentino de Paleontología y Bioestratigrafia, Resúmenes, 52. Trelew.

Casadio, A. \& Concheyro, A. 1992. Facies y ambientes de sedimentación en el límite Cretácico-Terciario de La Pampa, Argentina. III Congreso Geológico de España y VIII Congreso Latinoamericano de Geología. Actas, Vol. 4, 30-34. Salamanca.

Concheyro, A. 1991. Nanofósiles calcáreos de la Formación Man Aike (Eoceno, sudeste del lago Cardiel), Santa Cruz, Argentina. Ameghiniana, 28: 385-399.

Concheyro, A. \& Náñez, C. 1994. Microfossils and biostratigraphy of the Jagüel and Roca Formations (Maestrichtian-Danian), province of Neuquén. Ameghiniana, 31: 397.

Corliss, B. H. \& Chen, C. 1988. Morphotype patterns of Norwegian Sea deep-sea benthic foraminifera and ecological implications. Geology, 16: 716-719.

Fleming, C. A. 1962. New Zealand Biogeography: a paleontologist's approach. Tuatara, 10: 53-108.

Hornibrook, N. de B. 1961. Tertiary Foraminifera from Oamaru District (N.Z.). New Zealand Geological Survey, Paleontological Bulletin, 34: $1-192$.

Hrómic M. T. 1990. Presencia de Antarcticella (Candeina) antarctica (Leckie y Webb), (Protozoa, Foraminiferida, Candeinidae) en la cuenca Austral de América del Sur. Anales Instituto de la Patagonia Serie Ciencias Naturales, 18: 87-95.

Huber, B. 1988. Upper Campanian-Paleocene foraminifera from the James Ross Island region, Antarctic Peninsula. In Feldmann, R. M. \& Woodburne, M. O. (Eds), Geology and Paleontology of Seymour Island, Antarctica, Vol. 169, 163-252. Geological Society of America, Memoir.

Jenkins, D. G. 1966. Planktonic foraminiferal zones and new taxa from the Danian to Lower Miocene of New Zealand. New Zealand Journal of Geology and Geophysics, 8: 1088-1126.

Jenkins, D. G. 1985. Southern mid-latitude Paleocene to Holocene planktic foraminifera. In Bolli, H. M., Saunders, J. B. \& PerchNielsen, K. (Eds), Plankton Stratigraphy, 263-282. Cambridge University Press, Cambridge.

Leanza, H. A. \& Hugo, C. A. 1985. Los biohermas ostreros de la Formación Roca (Paleoceno) en el sudoeste de la Provincia de La Pampa, Argentina. Ameghiniana, 21: 143-149.

Levinton, J. S. 1970. The paleoecological significance of opportunistic species. Lethaia, 3: 69-78.

Loeblich, A. R. Jr. \& Tappan, H. 1987. Foraminiferal genera and their classification. Van Nostrand Reinhold, Co. New York.

Malumián, N. 1979. Esbozo paleoecológico de las asociaciones foraminiferológicas terciarias de la Argentina. Ameghiniana, 15: 161-181.

Malumián, N. 1982. Características bioestratigráficas de las asociaciones foraminiferológicas de la Argentina. $V$ Congreso Latinoamericano de Geología, Actas, Vol. 1, 779-790. Buenos Aires.

Malumián, N. 1989. Foraminíferos bentónicos de la localidad tipo de la Formación La Despedida (Eoceno, Isla Grande de Tierra del Fuego). Parte I, Textulariina y Miliolina. Ameghiniana, 25: 341-356.

Malumián, N. 1992. Foraminíferos de la Formación Man Aike (Eoceno, sureste Lago Cardiel), Provincia de Santa Cruz. Revista de la Asociación Geológica Argentina, 45: 365-385.

Malumián, N. 1993. El Eoceno medio marino del cono sur: Paleogeografia y foraminiferos. XII Congreso Geológico Argentino y II Congreso de Exploración de Hidrocarburos, Actas, II, 142-147. Buenos Aires.

Malumián, N. 1994. Foraminíferos nuevos o característicos del Eoceno medio de cuenca Austral: significado paleozoogeográfico. Ameghiniana, 31: 139-151.

Malumián, N. \& Caramés, A. 1995. El Daniano marino de Patagonia (Argentina): Paleobiogeografia de los foraminíferos bentónicos. Asociación Paleontológica Argentina, Publicación Especial No. 3 , Paleógeno de América del Sur, 83-105. Buenos Aires.

Malumián, N. \& Caramés, A. 1997. Upper Campanian-Paleogene from
Rio Turbio coal measures area: micropaleontology and the Paleocene/ Eocene boundary. Austral Basin, Argentina. Journal of South American Earth Sciences, 10(2): 189-201.

Malumián, N., Caramés, A. \& Náñez, C. 1995. El cambio en los foraminiferos bentónicos en el pasaje Cretácico-Paleógeno, cuencas Neuquina y del Colorado, Argentina. VI Congreso Argentino de Paleontologia y Bioestratigrafia, Actas, 173-178. Trelew.

Malumián, N. \& Masiuk, V. 1972. Boltovskoyella: A new Paleogene foraminiferal genus from Argentina. Journal of Foraminiferal Research, 2: 1-5.

Malumián, N., Masiuk, V. \& Riggi, J. C. 1971. Micropaleontología y sedimentología de la perforación SC-1, Provincia Santa Cruz, República Argentina. Su importancia y correlaciones. Revista de la Asociación Geológica Argentina, 26: 175-208.

Malumián, N. \& Náñez, C. 1989. Asociaciones de foraminíferos del Terciario medio de cuenca Austral: sus relaciones con eventos eustáticos globales. Revista de la Asociación Geológica Argentina, 43: 257-264.

Malumián, N. \& Náñez, C. 1991. Paleogeografía del Terciario medio del cono sur: avance de aguas antárticas. Sexto Congreso Geológico Chileno, Resumenes expandidos, 847-851. Santiago de Chile.

Malumián, N. \& Náñez, C. 1996. Microfósiles y nanofósiles calcáreos de la Plataforma Continental. In Ramos, V. A. and Turic, M. A. (Eds), Relatorio XIII Congreso Geológico Argentino y III Congreso de Exploración de Hidrocarburos (Buenos Aires, 1996). Geología y Recursos Naturales de la Plataforma Continental Argentina, 73-93. Buenos Aires.

Malumián, N. \& Ramos, V. 1984. Magmatic intervals, transgressionregression cycles and oceanic events in the Cretaceous and Tertiary of southern South America. Earth Planetary Science Letters, 67: 228237.

Martínez-Pardo, R. \& Martínez-Guzmán, R. 1989. Reinterpretation of Boltovskoyella (benthonic foraminiferal genus) as Neogene transandean chronostratigraphic event in southern South America. VIInter Congress, The Pacific, Bridge or Barrier?, 212.

Martini, E. 1971. Standard Tertiary and Quaternary calcareous nannoplankton zonation. In Farinacci, A. (Ed), Proceedings of the Second Conference on Planktonic Microfossils, Rome, 1970, Vol. 2, 739-85. Tecnoscienza, Rome.

Masiuk, V., Becker, D. \& Garcia Espiasse, A. 1976. Micropaleontología $y$ sedimentologia del pozo YPF Ch. Pves-1 (Peninsula Valdés), provincia del Chubut, Repuiblica Argentina. Importancia y correlaciones. ARPEL, XXIV Reunión a Nivel de expertos. Buenos Aires.

McDougall, K. 1987. Maestrichtian benthic foraminifers from Ocean Point, North Slope, Alaska. Journal of Foraminiferal Research, 17: 344-366.

Náñez, C. 1990. Foraminíferos y bioestratigrafia del Terciario medio de Santa Cruz oriental, Argentina. Revista de la Asociación Geológica Argentina, 43: 493-517.

Náñez, C. \& Concheyro, A. 1997. Limite Cretácico-Paleógeno. In Ardolino, A. \& Franchi, M. (Eds), Geológia y Recursos Minerales del Departamento Añelo, Provincia del Neuquén. República Argentina. Dirección Provincial de Minería, Boletín, 3 \& Dirección Nacional del Servicio Geológico, Anales, Vol. 25, 129-149. Buenos Aires.

Natland, M. L., González P., E., Cañón, A. \& Ernst, M. 1974. A system of stages for correlation of Magallanes basin sediments. Geological Society of America, Memoir, 139: 1-126.

Plummer, H. J. 1927. Foraminifera of the Midway Formation in Texas. University of Texas Bulletin, 2644: 1-206.

Ramos, V. 1981. Descripción geológica de la Hoja 33c, Los Chihuidos Norte, Provincia del Neuquén. Servicio Geológico Nacional, Boletín, 182: 1-103.

Revets, S.A. 1987. A revision of the genus Turrilina Andreae, 1884. Journal of Foraminiferal Research, 17: 321-332.

Stevens, G. R. 1973. The palaeogeographic history of New Zealand. The New Zealand Entomologist, 5: 230-239.

Stevens, G. R. 1980. Southwest Pacific faunal palaeobiogeography in Mesozoic and Cenozoic Times: a review. Palaeogeography, Palaeocli- 
matology, Palaeoecology, 31: 153-196.

Uliana, M. A. \& Dellape, D. A. 1981. Estratigrafia y evolución paleoambiental de la sucesión maestrichtiano-eoterciaria del engolfamiento neuquino (Patagonia septentrional). VIII Congreso Geológico Argentino, Actas, Vol. 3, 673-711. Buenos Aires.
Zinsmeister, W. J. 1979. Biogeographic significance of the Late Mesozoic and Early Tertiary molluscan faunas of Seymour Island (Antarctic Peninsula) to the final breakup of Gondwanaland. In Gray, J. \& Boucot, A. (Eds), Historical Biogeography, Plate Tectonics and the Changing Environment. Proc. 37th Ann. Biol. Colloquium and Selected Paper, 349-355. Oregon State University Press, Corvallis. 